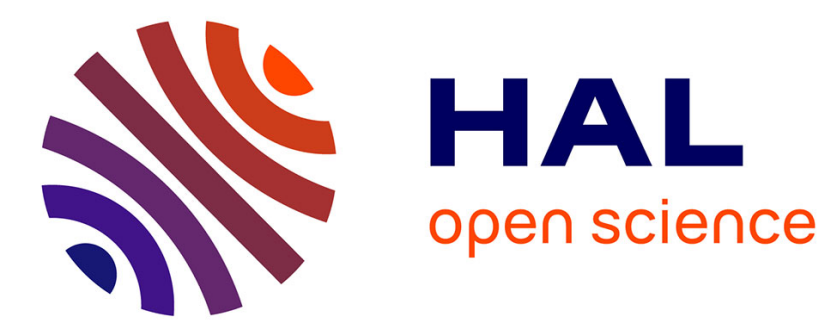

\title{
Differential role of TRP channels in prostate cancer
}

Natalia Prevarskaya, Matthieu Flourakis, Gabriel Bidaux, Stephanie

Thebault, R. Skryma

\section{To cite this version:}

Natalia Prevarskaya, Matthieu Flourakis, Gabriel Bidaux, Stephanie Thebault, R. Skryma. Differential role of TRP channels in prostate cancer. Conference on Cell and Molecular Biology of TRP Channels, 2006, Bath, United Kingdom. pp.133-135, 10.1042/BST0350133 . hal-03060256

\section{HAL Id: hal-03060256 https://hal.science/hal-03060256}

Submitted on 13 Dec 2020

HAL is a multi-disciplinary open access archive for the deposit and dissemination of scientific research documents, whether they are published or not. The documents may come from teaching and research institutions in France or abroad, or from public or private research centers.
L'archive ouverte pluridisciplinaire HAL, est destinée au dépôt et à la diffusion de documents scientifiques de niveau recherche, publiés ou non, émanant des établissements d'enseignement et de recherche français ou étrangers, des laboratoires publics ou privés. 


\section{Differential role of TRP channels in prostate cancer.}

Natalia Prevarskaya ${ }^{1}$, Matthieu Flourakis, Gabriel Bidaux, Stephanie Thebault, Roman Skryma.

Inserm, U-800, Equipe labellisée par la Ligue Nationale contre le cancer, Villeneuve d'Ascq, F-59655 France; Université des Sciences et Technologies de Lille (USTL), Villeneuve d'Ascq, F-59655 France

${ }^{1}$ Correspondence address : Natalia Prevarskaya, Laboratoire de Physiologie Cellulaire, INSERM U800, Bâtiment SN3, USTL, 59655 Villeneuve d'Ascq, France; Tel.: 33-3-20-434077; Fax: 33-3-20-43-4066; E-mail: Natacha.Prevarskaya@univ-lille1.fr 


\begin{abstract}
Major clinical problem with prostate cancer is the cell's ability to survive and proliferate upon androgen withdrawal. Indeed, deregulated cell differentiation and proliferation together with the suppression of apoptosis provides the condition for abnormal tissue growth. Here we examine the differential role of TRP channels in the control of $\mathrm{Ca}^{2+}$ homeostasis and growth of prostate cancer cells.
\end{abstract}

Key words: prostate cancer, calcium, TRP channels, differentiation, proliferation, apoptosis

\title{
Introduction
}

Prostate cancer (PC) is one of the leading threats to men's health. Its early stage depends on androgens for growth and survival, and androgen ablation therapy may at this time be effective in causing tumor to regress, however, in the late androgen-independent stage there is currently no successful therapy. It is, therefore, vital to understand what drives the progression to androgen independence. This latter is associated with the appearance of new cell phenotypes, characterized by apoptosis inhibition and the aberrant cell proliferation. Deregulated cell differentiation and proliferation together with the suppression of apoptosis provide the condition for abnormal tissue growth, which ultimately can turn into uncontrolled expansion and invasion characteristic of cancer.

The role of calcium $\left(\mathrm{Ca}^{2+}\right)$ in the overall of cancer-related cell signalling pathways is uncontested. Alterations in $\mathrm{Ca}^{2+}$ homeostasis have been described to increase proliferation [1, 2], to induce differentiation [3] or apoptosis [4-6]. According to a growing number of studies, cationic channels in the TRP (Transient Receptor Potential) family would be key players of 
calcium homeostasis and cell physiopathology. During the last years it has emerged that several members of the TRP family could play an important role in prostate carcinogenesis and even more, some of them have been suggested as a prognostic markers for PCa especially useful in the differential diagnosis [6].

Here we examine the differential role of TRP channels in $\mathrm{Ca}^{2+}$ homeostasis of $\mathrm{PC}$ epithelial cells and their respective role in prostate carcinogenesis. Recent progress achieved in our understanding of molecular mechanisms of TRP channels signalling involved in the control of PC progression ensures that sooner or later fundamental breakthroughs will make their way to practical implications.

\section{Agonist-dependent growth regulation of human PC epithelial cells: role of TRPC}

\section{channels}

Various growth factors, neurotransmitters and hormones, known to control physiological and pathological cell proliferation, participate in the maintenance of intracellular $\mathrm{Ca}^{2+}$ homeostasis. Although the nature of these agonists has yet to be wellestablished during prostate cancer progression, they invariably induce a $\mathrm{Ca}^{2+}$ entry called "agonist-induced $\mathrm{Ca}^{2+}$ entry" (ACE). Using the androgen-dependent LNCaP cell line and primary cultures of human prostate cancer epithelial cells established from resection specimens we have demonstrated that $\alpha 1$-adrenergic receptors ( $\alpha 1$-ARs) stimulation activates non-specific cationic channels leading to ACE [7].

Interestingly, we have also shown that in contrast to the stimulatory role of $\alpha 1$-ARs on prostate cancer cell growth, metabotropic purinergic receptors (P2Y-R) are involved in the growth arrest of human prostate cancer cells [8]. Such divergent effects of two receptors on cell proliferation are surprising, since both $\alpha 1-\mathrm{AR}$ and P2Y-R are known to be coupled to the common phospholipase $\mathrm{C}$ catalyzed inositol phospholipids breakdown signalling pathway, via 
which $\alpha 1$-agonists and extracellular ATP could apparently induce similar increases in intracellular free $\mathrm{Ca}^{2+}\left(\left[\mathrm{Ca}^{2+}\right]_{\mathrm{i}}\right.$. The opposite effects on cell proliferation can only be explained if the ACE controlled by each receptor utilizes different $\mathrm{Ca}^{2+}$-permeable membrane channels ultimately destined to target various intracellular effectors. We have shown that the pattern of $\mathrm{Ca}^{2+}$ signalling initiated by $\alpha 1-\mathrm{AR}$ stimulation is characterized by regular oscillatory activity, which is almost exclusively based on $\mathrm{Ca}^{2+}$ entry pathway directly gated by DAG with no apparent role for $\mathrm{IP}_{3}$-mediated store depletion. In contrast, $\mathrm{Ca}^{2+}$ signalling coupled to $\mathrm{P} 2 \mathrm{Y}-\mathrm{R}$ stimulation is largely determined by $\mathrm{IP}_{3}$-mediated store-dependent processes including robust $\mathrm{Ca}^{2+}$ release and the activation of store-operated $\mathrm{Ca}^{2+}$ influx.

Our results highlight the importance of $\mathrm{Ca}^{2+}$ entry pathways in the discrimination of the signalling via $\alpha 1$-adrenergic and P2Y-purinergic receptors in hPCE cells. Indeed, the $\alpha 1$-AR agonists activate $\mathrm{Ca}^{2+}$ entry mainly via the TRPC6 channel, whereas ATP-evoked $\mathrm{Ca}^{2+}$ entry predominantly involves TRPC1 and TRPC4 channels. TRPC6 silencing by antisense hybrid depletion or by siRNA decreased both hPCE cell proliferation and ACE. In contrast, ACE and related growth arrest associated with P2Y-R stimulation involved neither TRPC6 nor NFAT. Thus, TRPC6 channel (which determines the oscillatory pattern of $\mathrm{Ca}^{2+}$ signaling coupling the agonist-mediated $\alpha 1$-AR stimulation to $\mathrm{Ca}^{2+}$-dependent activation of the NFAT transcription factor) could potentially represent a suitable target for therapeutic intervention.

TRPM8 localization and function in prostate depends on the differentiation status: role in carcinogenesis

TRPM8 is a so-called "cold" receptor belonging to melastatin (TRPM) subfamily of TRP channels and is activated by cooling temperatures and menthol. Aside from sensory neurons, in which the role of TRPM8 in mediating cold-evoked excitation is fairly well established [9, 10], this channel is most abundantly expressed in the prostate. In fact, TRPM8 was first cloned from the human prostate as prostate-specific gene [11], even before its role in the cold 
sensation was established. Moreover, whilst remaining at moderate levels in normal prostate, TRPM8 expression strongly increases in prostate cancer. Despite the growing numbers of studies, the role of TRPM8 in prostate remains unclear, and it has been suggested to be involved in secretion function of the prostate and in the regulation of proliferation and/or apoptosis $[12,13]$

It has been also shown that anti-androgen therapy greatly reduced the expression of TRPM8, suggesting that TRPM8 is regulated by androgens [14]. We have demonstrated that in prostate cancer cell lines, and in primary cultures of normal, hyperplasic and cancerous prostate epithelial cells, TRPM8 is a target gene of the androgen receptor [12]. TRPM8 expression silencing experiments using siRNA suggest that the $\mathrm{Ca}^{2+}$ inflow through TRPM8 plays an essential role in cellular $\mathrm{Ca}^{2+}$ homeostasis in prostate epithelial cells and is involved in cell survival [13].

Our results [15] and those of Barrit's group [13] indicate that TRPM8 may be expressed not just in the plasma membrane, but also in the endoplasmic reticulum (ER) membrane. Dual localization and channel-like function of TRPM8 in the two membranes significantly broaden the spectrum of physiological and pathological processes it may be involved in. However, the mechanisms which determine the preferred localization of TRPM8 in cells of different phenotypes are not known so far. Our results demonstrate that only highly differentiated human prostate primary luminal epithelial cells express functional plasma membrane (PMTRPM8) channels. Moreover, prostate epithelium cancer cells (obtained from in situ prostate cancers) were characterized by significantly larger PMTRPM8-mediated current density than normal cells. We have shown that this PMTRPM8 activity was abolished in dedifferentiated cells that had lost their luminal secretory phenotype. However, we found that, in contrast to PMTRPM8, endoplasmic reticulum TRPM8 (ERTRPM8) remained functional (as an $\mathrm{ER} \mathrm{Ca}^{2+}$ release channel), independently of its differentiation status. Furthermore, similarly 
to dedifferentiated prostate epithelial cells, metastatic, LNCaP (lymph node carcinoma of the prostate) cells also exhibited most exclusive TRPM8 localization in the ER [15]. We hypothesize (Figure 1) that in prostate, TRPM8 localization may depend on epithelial cell phenotype (i.e. fully differentiated secretory apical cells vs. non-differentiated basal cells) and on androgen status (i.e. androgen-dependent vs. hormone refractory cells highly resistant to apoptosis). Taken together, these data suggest that TRPM8 may contribute to the initiation, promotion and progression of carcinogenesis in prostate epithelial cells.

\section{Acknowledgements}

This work was supported by grants from INSERM, Ministère de l'Education, La Ligue Nationale Contre le Cancer and the region Nord/Pas-de-Calais.

\section{References}

1 Legrand, G., Humez, S., Slomianny, C., Dewailly, E., Vanden Abeele, F., Mariot, P., Wuytack, F. and Prevarskaya, N. (2001) J Biol Chem 276, 47608-14

2 Thebault, S., Flourakis, M., Vanoverberghe, K., Vandermoere, F., Roudbaraki, M., Lehen'kyi, V., Slomianny, C., Beck, B., Mariot, P., Bonnal, J. L., Mauroy, B., Shuba, Y., Capiod, T., Skryma, R. and Prevarskaya, N. (2006) Cancer Res 66, 2038-47

3 Vanoverberghe, K., Vanden Abeele, F., Mariot, P., Lepage, G., Roudbaraki, M., Bonnal, J. L., Mauroy, B., Shuba, Y., Skryma, R. and Prevarskaya, N. (2004) Cell Death Differ 11, 321-30

4 Skryma, R., Mariot, P., Bourhis, X. L., Coppenolle, F. V., Shuba, Y., Vanden Abeele, F., Legrand, G., Humez, S., Boilly, B. and Prevarskaya, N. (2000) J Physiol 527 Pt 1, $71-83$ 
5 Vanden Abeele, F., Skryma, R., Shuba, Y., Van Coppenolle, F., Slomianny, C., Roudbaraki, M., Mauroy, B., Wuytack, F. and Prevarskaya, N. (2002) Cancer Cell 1, $169-79$

6 Zhang, L. and Barritt, G. J. (2006) Endocr Relat Cancer 13, 27-38

7 Thebault, S., Roudbaraki, M., Sydorenko, V., Shuba, Y., Lemonnier, L., Slomianny, C., Dewailly, E., Bonnal, J. L., Mauroy, B., Skryma, R. and Prevarskaya, N. (2003) J Clin Invest 111, 1691-701

8 Vanoverberghe, K., Mariot, P., Vanden Abeele, F., Delcourt, P., Parys, J. B. and Prevarskaya, N. (2003) Cell Calcium 34, 75-85

9 McKemy, D. D., Neuhausser, W. M. and Julius, D. (2002) Nature 416, 52-8

10 Peier, A. M., Moqrich, A., Hergarden, A. C., Reeve, A. J., Andersson, D. A., Story, G. M., Earley, T. J., Dragoni, I., McIntyre, P., Bevan, S. and Patapoutian, A. (2002) Cell 108, $705-15$

11 Tsavaler, L., Shapero, M. H., Morkowski, S. and Laus, R. (2001) Cancer Res 61, $3760-9$

12 Bidaux, G., Roudbaraki, M., Merle, C., Crepin, A., Delcourt, P., Slomianny, C., Thebault, S., Bonnal, J. L., Benahmed, M., Cabon, F., Mauroy, B. and Prevarskaya, N. (2005) Endocr Relat Cancer 12, 367-82

13 Zhang, L. and Barritt, G. J. (2004) Cancer Res 64, 8365-73

14 Henshall, S. M., Afar, D. E., Hiller, J., Horvath, L. G., Quinn, D. I., Rasiah, K. K., Gish, K., Willhite, D., Kench, J. G., Gardiner-Garden, M., Stricker, P. D., Scher, H. I., Grygiel, J. J., Agus, D. B., Mack, D. H. and Sutherland, R. L. (2003) Cancer Res 63, 4196-203 
15 Thebault, S., Lemonnier, L., Bidaux, G., Flourakis, M., Bavencoffe, A., Gordienko,

D., Roudbaraki, M., Delcourt, P., Panchin, Y., Shuba, Y., Skryma, R. and

Prevarskaya, N. (2005) J Biol Chem 280, 39423-35

\section{Figure 1.}



Schematic diagram showing in simplified form differential TRPM8 localization and function depending on AR activity of human prostate epithelial cells and on their differentiation status. 